\title{
Article \\ Carbapenemase Producing Klebsiella pneumoniae (KPC): What Is the Best MALDI-TOF MS Detection Method
}

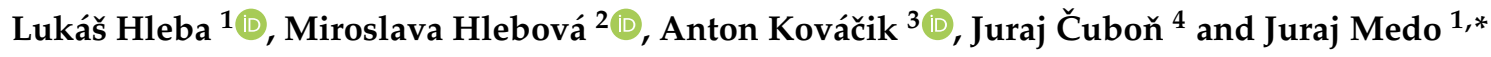 \\ 1 Institute of Biotechnology, Faculty of Biotechnology and Food Sciences, Slovak University of Agriculture, \\ Trieda Andreja Hlinku 2, 94976 Nitra, Slovakia; lukas.hleba@uniag.sk \\ 2 Department of Biology, Faculty of Natural Sciences, University of Ss. Cyril and Methodius in Trnava, Nám. \\ Jána Herdu 577/2, 91701 Trnava, Slovakia; miroslava.hlebova@ucm.sk \\ 3 Institute of Applied Biology, Faculty of Biotechnology and Food Sciences, Slovak University of Agriculture, \\ Trieda Andreja Hlinku 2, 94976 Nitra, Slovakia; anton.kovacik@uniag.sk \\ 4 Institute of Food Sciences, Faculty of Biotechnology and Food Sciences, Slovak University of Agriculture, \\ Trieda Andreja Hlinku 2, 94976 Nitra, Slovakia; juraj.cubon@uniag.sk \\ * Correspondence: juraj.medo@uniag.sk
}

check for updates

Citation: Hleba, L.; Hlebová, M.; Kováčik, A.; Čuboň, J.; Medo, J. Carbapenemase Producing Klebsiella pneumoniae (KPC): What Is the Best MALDI-TOF MS Detection Method. Antibiotics 2021, 10, 1549. https:// doi.org/10.3390/antibiotics10121549

Academic Editor: Daniel V. Zurawski

Received: 15 November 2021

Accepted: 16 December 2021

Published: 17 December 2021

Publisher's Note: MDPI stays neutral with regard to jurisdictional claims in published maps and institutional affiliations.

Copyright: (c) 2021 by the authors Licensee MDPI, Basel, Switzerland. This article is an open access article distributed under the terms and conditions of the Creative Commons Attribution (CC BY) license (https:/ / creativecommons.org/licenses/by/ $4.0 /)$.

\begin{abstract}
Klebsiella pneumoniae carbapenemase (KPC)-producing bacteria is a group of highly dangerous antibiotic resistant Gram-negative Enterobacteriaceae. They cause infections associated with significant morbidity and mortality. Therefore, the rapid detection of KPC-producing bacteria plays a key role in clinical microbiology. Matrix assisted laser desorption/ionization time-of- flight (MALDI-TOF) is a rapidly evolving technology that finds application in various clinical, scientific, and industrial disciplines. In the present study, we demonstrated three different procedures of carbapenemase-producing K. pneumoniae (KPC) detection. The most basic model of MALDI-TOF instrument MS Microflex LT was used, operating in the linear ion-positive mode, commonly used in modern clinical laboratories. The first procedure was based on indirect monitoring of carbapenemase production with direct detection of hydrolyzed carbapenem antibiotic degradation products in the mass spectrum. The second procedure was based on direct detection of $b l a_{\mathrm{KPC}}$ accompanying peak with an 11,109 Da in the mass spectrum of carbapenemase-producing K. pneumoniae (KPC), which represents the cleaved protein (pKpQIL_p019) expressed by pKpQIL plasmid. In addition, several unique peaks were detected in the carbapenemase-producing K. pneumoniae (KPC) mass spectrum. The third procedure was the identification of carbapenemase-producing K. pneumoniae (KPC) based on the protein fingerprint using local database created from the whole mass spectra. By comparing detection procedures, we determined that the third procedure was very fast and relatively easy. However, it requires previous verification of carbapenemase-producing K. pneumoniae (KPC) using other methods as genetic $b l a_{\mathrm{KPC}}$ identification, detection of carbapenem degradation products, and accompanying peak with 11,109 Da, which represents cleaved pKpQIL_p019 protein expressed by pKpQIL plasmid. Detection of carbapenemase-producing K. pneumoniae using MALDI-TOF provides fast and accurate results that may help to reduce morbidity and mortality in hospital setting when applied in diagnostic situations.
\end{abstract}

Keywords: Klebsiella pneumoniae; KPC; MALDI-TOF MS; detection

\section{Introduction}

Klebsiella pneumoniae is a species of Gram-negative bacteria that belongs to the Enterobacteriaceae family [1]. It contaminates different types of food products, including plant raw materials such as sprouts and salads [2], raw vegetables [3], or fresh fruits [4]. It is an important opportunistic pathogen causing frequent nosocomial infections [5], mainly infections of the urinary and respiratory tract [6]. Highly dangerous and rapidly spread strains are represented by carbapenemase-producing K. pneumoniae (KPC) often associated with hospital and nosocomial infections, resulting in high morbidity and mortality [7]. Carbapenems 
are a class of antibiotics that are often used for treatment of Gram-negative bacteria producing extended-spectrum $\beta$-lactamases (ESBL) [8]. Carbapenemase-producing K. pneumoniae (KPC) and their carbapenemase are classified as class-A, according to Ambler classification of beta-lactamases. Carbapenemase gene is located on plasmids and can hydrolyze all types of penicillins, carbapenems, cephalosporins, and aztreonam [9]. Therefore, the identification of carbapenemase-producing K. pneumoniae (KPC) is essential for clinical microbiology mainly. There are several methods for detection of carbapenemase-producing bacteria, such as screening for carbapenemase-production based on disk diffusion methodology using meropenem and ertapenem disks or minimal inhibition concentration [10], combination disk testing [11], biochemical (colorimetric) test [12], carbapenem inactivation method [13], detection of carbapenem hydrolysis with MALDI-TOF MS (matrix-assisted laser desorption/ionization time-of-flight mass spectrometry) [14] or lateral flow assay [15]. These established methods are described in EUCAST guidelines for the detection of resistance mechanisms and specific resistances of clinical and/or epidemiological importance [16]. In addition, newer and faster methods became available in recent years. Today, one of the most common methods used in clinical microbiology is MALDI-TOF MS [17]. The use of MALDI-TOF MS is rapid, robust, and with a low cost per sample. New MALDI-TOF MS approaches for discrimination of bacterial species are emerging recently. They are based on detailed analysis of bacterial proteome by high-resolution mass spectra [18]. Discrimination of microorganisms at the strain level was described in many cases as genetic 16S rRNA sequencing [19], single nucleotide polymorphisms [20], metagenomic sequencing [21], whole-genome sequencing [22], ribosomal multi-locus sequencing [23] or laser induced breakdown spectroscopy and neural networks [24]. Genetic analysis including cell lysis and DNA extraction is time consuming, requires experienced technicians, and is also expensive $[22,25,26]$. In contrast, MALDI-TOF is easier, faster, cheaper, more accurate, and allows for the identification of closely related microbial strains [27-31]. Moreover, the analysis of unique protein biomarkers in the obtained mass spectrum allows discrimination of bacteria at the strain level [32]. Recently, many applications of MALDI-TOF MS were developed for discrimination of bacteria at the strain level such as discrimination of mycobacteria [33], E. coli [32], Arthrobacter isolates [34], Enterococcus faecium and Staphylococcus aureus strains [35], Bacillus cereus group [36], highly risk Escherichia coli serotypes [37], phylotypes of Propionibacterium acnes [38], and many more.

Therefore, the aim of our study was to demonstrate ability of MALDI-TOF MS to distinguish carbapenemase-producing K. pneumoniae (KPC) from non-KPC strains. Three identification procedures using MALDI-TOF MS namely (1) hydrolysis of carbapenem antibiotic, (2) specific K. pneumoniae (KPC) accompanying peak with 11,109 Da, and (3) building of a local database of spectra for discrimination of both types of K. pneumoniae were compared.

\section{Results and Discussion}

\subsection{Verification of Carbapenemase-Producing Klebsiella pneumoniae (KPC)}

The disk diffusion methodology showed that all K. pneumoniae isolates from small fruits were susceptible to meropenem with a zone diameter higher than $22 \mathrm{~mm}$ and $28 \mathrm{~mm}$ which represents the screening cut-off value. Only K. pneumoniae isolates from patient showed zone diameter smaller than $16 \mathrm{~mm}$. Minimal inhibitory concentration (MIC) was evaluated by MIC Evaluators strips. Klebsiella pneumoniae (KPC) showed resistance against meropenem as MIC values were higher than $8 \mathrm{mg} / \mathrm{L}$ and screening cutoff represents $0.125 \mathrm{mg} / \mathrm{L}$. Others K. pneumoniae isolates showed susceptibility ( $\leq 2 \mathrm{mg} / \mathrm{L}$ and smaller than the cut-off value) against meropenem.

Combination disk testing with algorithm for carbapenemase detection was tested against all strains of K. pneumoniae. Results confirmed that patient K. pneumoniae isolates carried KPC resistance because boronic acid inhibited class A carbapenemase only.

Genetic analysis based on PCR amplification of $b l a_{\mathrm{KPC}}$ genes confirmed presence of the gene solely in the isolates from clinical samples. PCR product with approx. $900 \mathrm{bp}$ was 
observed on electrophoresis gel. PCR testing showed no amplification for isolates from small berries.

\subsection{Indirect Detection of Enzymatic Hydrolysis}

Indirect detection of enzymatic hydrolysis included detection of pure antibiotic (meropenem) as standard, and all degradation products of hydrolyzed meropenem. Meropenem was detected as three peaks complex in the mass spectrum with $384.098 \mathrm{~m} / \mathrm{z}$ $\left(\right.$ meropenem $\left.[\mathrm{M}+\mathrm{H}]^{+}\right), 406.265 \mathrm{~m} / \mathrm{z}\left(\right.$ meropenem sodium salt $\left.[\mathrm{M}+\mathrm{Na}]^{+}\right)$and $428.057 \mathrm{~m} / \mathrm{z}$ (meropenem disodium salt $[\mathrm{M}+2 \mathrm{Na}]^{+}$) (Figure 1 -meropenem). Similar methodology for carbapenem-resistant K. pneumoniae was used by Sakarikou et al. [39] who detected ertapenem by MALDI-TOF MS as three peaks complex: ertapenem with $476.5 \mathrm{~m} / z[\mathrm{M}+\mathrm{H}]^{+}$, ertapenem sodium salt with $498.5 \mathrm{~m} / z[\mathrm{M}+\mathrm{Na}]^{+}$, and ertapenem disodium salt with $520.5 \mathrm{~m} / z[\mathrm{M}+2 \mathrm{Na}]^{+}$. Ertapenem was used for quick K. pneumoniae resistance detection also by $\mathrm{Yu}$ et al. [40] who observed the same mass spectrum as Sakarikou et al. [39]. Meropenem for indirect detection of enzymatic hydrolysis in K. pneumoniae KPC was applied by Wang et al. [41]. The same mass spectrum as in our study was detected. In all these experiments, carbapenem mass spectra were measured in the range from 300 to $500 \mathrm{~m} / \mathrm{z}$. Most authors used HCCA as matrix because it shows better-quality mass spectra of small molecules than DHB acid. After alkaline hydrolysis, degradation products of meropenem were identified as a mass spectrum with the peaks, as follows: $379.104 \mathrm{~m} / \mathrm{z}$ (decarboxylated meropenem sodium salt), $401.424 \mathrm{~m} / \mathrm{z}$ (meropenem with cleaved amide bond), $422.850 \mathrm{~m} / z$ (meropenem sodium salt with cleaved amide bond) and $445.119 \mathrm{~m} / \mathrm{z}$ (meropenem disodium salt with cleaved amide bond) (Figure $1-$ meropenem $+\mathrm{NaOH}$ ). Alkaline hydrolysis of antibiotics by sodium hydroxide as a comparative model of degradation products was used by all authors in their studies [28,39-44].

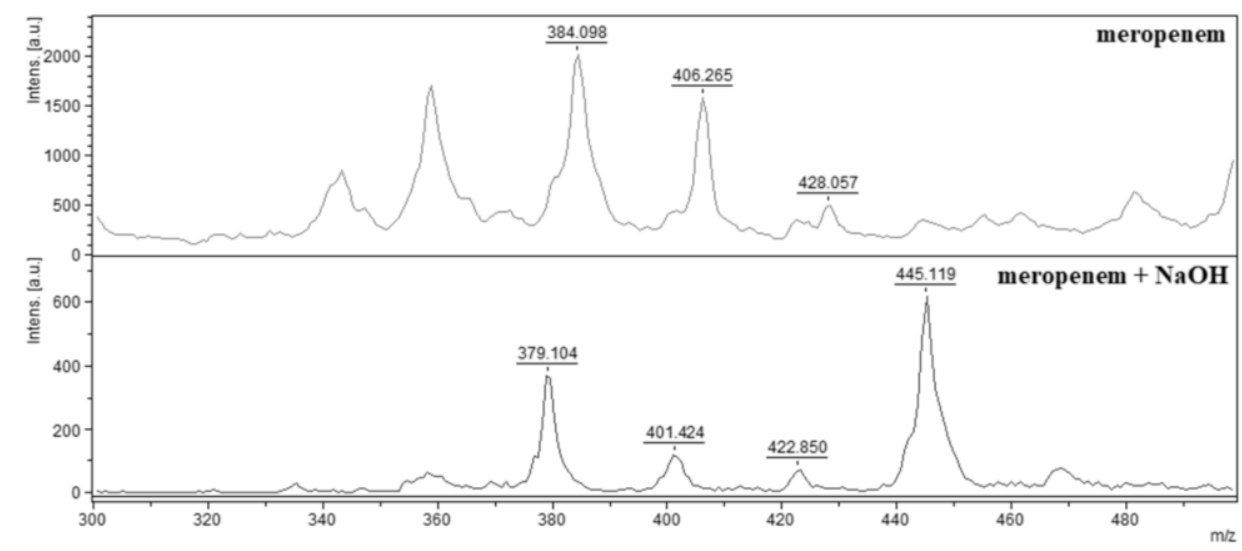

Figure 1. Mass spectra of meropenem and alkaline hydrolyzed meropenem. Meropenem$384.098 \mathrm{~m} / \mathrm{z}[\mathrm{M}+\mathrm{H}]^{+}$, meropenem sodium salt-406.265 $\mathrm{m} / \mathrm{z}[\mathrm{M}+\mathrm{Na}]^{+}$, meropenem disodium salt-428.057 $\mathrm{m} / \mathrm{z}[\mathrm{M}+2 \mathrm{Na}]^{+}$. Alkaline hydrolyzed meropenem: decarboxylated meropenem sodium salt-379.104 m/z $\left[\mathrm{M}-\mathrm{CO}_{2}+\mathrm{H}\right]^{+}$, meropenem with cleaved amide bond $-401.424 \mathrm{~m} / \mathrm{z}[\mathrm{M}+\mathrm{H}]^{+}$, meropenem sodium salt with cleaved amide bond $-422.850 \mathrm{~m} / z[\mathrm{M}+\mathrm{Na}]^{+}$and meropenem disodium salt with cleaved amide bond $-445.119 \mathrm{~m} / z[\mathrm{M}+2 \mathrm{Na}]^{+}$.

Meropenem-resistant and -susceptible isolates of K. pneumoniae were incubated in Tris$\mathrm{HCl}$ ( $\mathrm{pH}$ 7.0) solution supplemented with meropenem. The same solution has been used as buffer by many authors [45-47]. Susceptible K. pneumoniae did not degrade meropenem and the resulting mass spectrum was identical to that of pure meropenem, described above. In contrast, the mass spectrum obtained from carbapenem-resistant K. pneumoniae was the same as the degradation products after alkaline hydrolysis of meropenem. The following peaks were observed: $380.055 \mathrm{~m} / \mathrm{z}$ (decarboxylated meropenem sodium salt), $402.338 \mathrm{~m} / \mathrm{z}$ (meropenem with cleaved amide bond), $423.945 \mathrm{~m} / \mathrm{z}$ (meropenem sodium 
salt with cleaved amide bond) and $446.575 \mathrm{~m} / \mathrm{z}$ (meropenem disodium slat with cleaved amide bond) (Figure 2). For example, Mirande et al. [44] detected hydrolytic cleavage of ertapenem and faropenem with degradation products, as follows: ertapenem with 450, 472 and $494 \mathrm{~m} / \mathrm{z}$ and faropenem with 304,326 and $348 \mathrm{~m} / \mathrm{z}$.

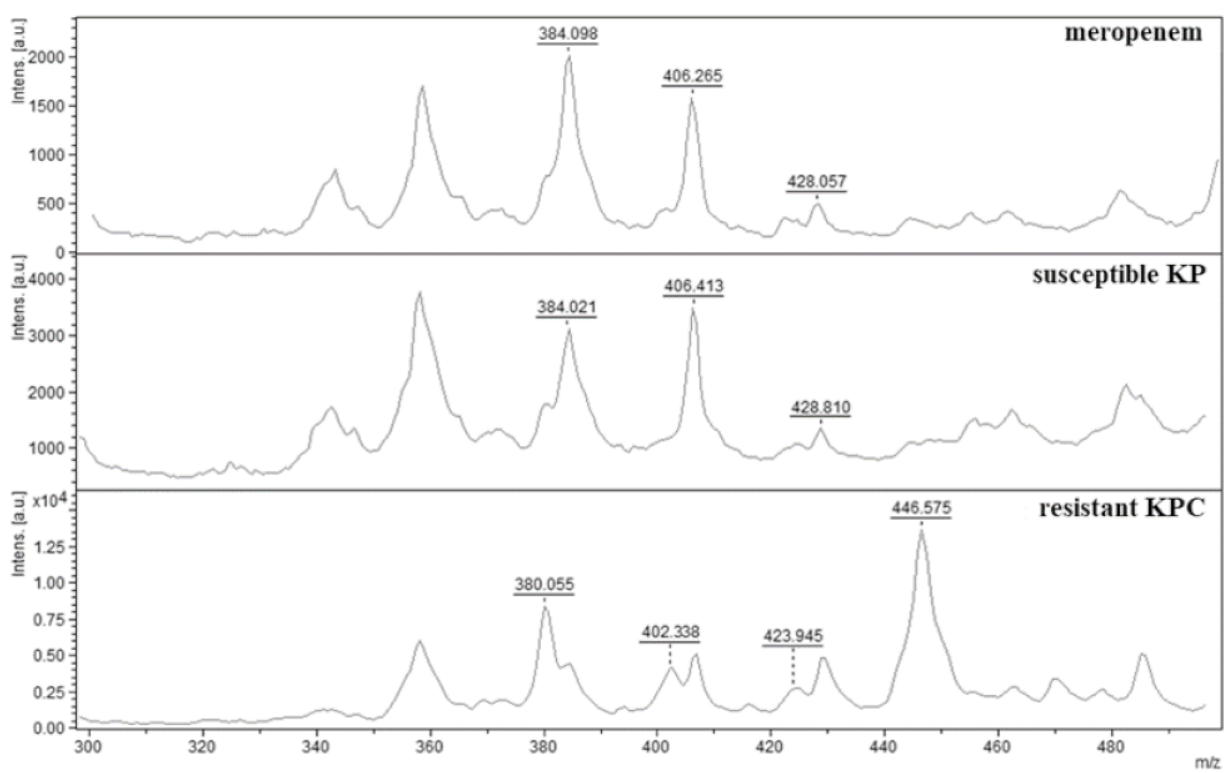

Figure 2. MALDI-TOF mass spectra of meropenem, its sodium salts and degradation products. Meropenem-mass spectrum of meropenem. Susceptible KP-mass spectrum of meropenem in negative control with susceptible K. pneumoniae. Resistant KPC-mass spectrum of meropenem degradation products with resistant K. pneumoniae KPC. Mass spectra: 384.098 and $384.021 \mathrm{~m} / \mathrm{z}$ (meropenem), 406.264 and $406.413 \mathrm{~m} / z$ (meropenem sodium salt), 428.057 and $428.810 \mathrm{~m} / \mathrm{z}$ (meropenem disodium salt), $380.055 \mathrm{~m} / \mathrm{z}$ (decarboxylated meropenem sodium salt), $402.338 \mathrm{~m} / \mathrm{z}$ (meropenem with cleaved amide bond), $423.945 \mathrm{~m} / \mathrm{z}$ (meropenem sodium salt with cleaved amide bond) and $446.575 \mathrm{~m} / \mathrm{z}$ (meropenem disodium salt with cleaved amide bond).

Hrabák et al. [48] hydrolyzed meropenem by carbapenem-resistant bacteria, with Verona imipenemase (VIM) producing Pseudomonas aeruginosa, K. pneumoniae, Serratia marcescens, and Enterobacter cloacae, imipenemase (IMP) producing P. aeruginosa, KPC K. pneumoniae, and New Delhi metallo- $\beta$-lactamase (NDM-1) producing K. pneumoniae. Subsequently, meropenem trisodium salt with cleaved amide bond $(467.839 \mathrm{~m} / \mathrm{z})$ was detected. In our study, such a degradation product was not observed. Rotova et al. [45] described a method of VIM producing $P$. aeruginosa discrimination based on the detection of hydrolyzed meropenem and meropenem sodium salt [45]. When imipenem is used to detect carbapenemases by MALDITOF MS, then it can be also used to detect degradation of carbapenem-resistant species from the OXA-48, KPC, and NDM classes. However, it is not appropriate for the extended-spectrum $\beta$-lactamase (ESBL) producers [49]. In our experiment using meropenem, it was possible to identify $\beta$-lactamase with an extended spectrum of action (ESBL), which is also confirmed by the results of other authors [48,50]. By detecting degradation products of meropenem, we could confirm the enzymatic hydrolysis of meropenem carbapenem-resistant K. pneumoniae KPC. In parallel, a mechanism of resistance commonly called enzymatic destruction of antibiotics has been confirmed. The following table (Table 1) summarizes the relative weights of molecules of native and hydrolyzed or decarboxylated forms of carbapenem antibiotics analyzed by mass spectrometry. For monitoring carbapenem resistance in bacteria it is very important. 
Table 1. Native and hydrolyzed forms of carbapenem antibiotics detected by MALDI-TOF mass spectrometry $(\mathrm{m} / \mathrm{z})$.

\begin{tabular}{|c|c|c|c|c|c|c|c|c|}
\hline \multirow[t]{2}{*}{ C-ATB } & \multicolumn{4}{|c|}{ Native Forms of ATB $(\mathrm{m} / \mathrm{z})$} & \multicolumn{4}{|c|}{ Hydrolyzed Forms of ATB $(\mathrm{m} / \mathrm{z})$} \\
\hline & {$[\mathrm{M}+\mathrm{H}]^{+}$} & {$[\mathrm{M}+\mathrm{Na}]^{+}$} & {$[\mathrm{M}+2 \mathrm{Na}]^{+}$} & {$[\mathrm{M}+3 \mathrm{Na}]^{+}$} & {$[\mathrm{M}+\mathrm{H}]^{+}$} & {$[\mathrm{M}+\mathrm{Na}]^{+}$} & {$[\mathrm{M}+2 \mathrm{Na}]^{+}$} & {$[\mathrm{M}+3 \mathrm{Na}]^{+}$} \\
\hline Meropenem & $382^{1,2,3}$ & $405^{1,2,3}$ & $427^{1,2,3}$ & & $401^{2,3}$ & $423^{2,3}$ & $445^{2,3}$ & $467^{2}$ \\
\hline Ertapenem & $476^{1,4}$ & $498^{1,4,5}$ & $520^{1,4,5}$ & $542^{1,4}$ & $494^{1,4}$ & $516^{1,4}$ & $538^{1,4}$ & $560^{4}$ \\
\hline \multirow[t]{3}{*}{ Faropenem } & $286^{4}$ & $308^{4}$ & $330^{4}$ & $352^{4}$ & $304^{4}$ & $326^{4}$ & $348^{4}$ & $370^{4}$ \\
\hline & \multicolumn{4}{|c|}{ Native forms of ATB } & \multicolumn{4}{|c|}{ Decarboxylated forms of ATB } \\
\hline & {$[\mathrm{M}+\mathrm{H}]^{+}$} & {$[\mathrm{M}+\mathrm{Na}]^{+}$} & {$[\mathrm{M}+2 \mathrm{Na}]^{+}$} & {$[\mathrm{M}+3 \mathrm{Na}]^{+}$} & \multicolumn{2}{|c|}{$\left[\mathrm{M}+\mathrm{H}_{2} \mathrm{O}-\mathrm{CO}_{2}+\mathrm{H}\right]^{+}$} & \multicolumn{2}{|c|}{$\left[\mathrm{M}+\mathrm{H}_{2} \mathrm{O}-\mathrm{CO}_{2}+\mathrm{Na}\right]^{+}$} \\
\hline Imipenem & $300^{1}$ & $322^{5}$ & & & \multicolumn{2}{|c|}{$274^{5}$} & \multicolumn{2}{|c|}{$296^{5}$} \\
\hline
\end{tabular}

\subsection{Identification of bla ${ }_{K P C}$ Accompanying Peak with 11,109 Da}

The mass spectrum of susceptible and resistant K. pneumoniae was obtained using a standard procedure for protein isolation in ethanol-formic acid-acetonitrile extractant. Subsequent crystallization of the sample was performed using HCCA cinnamic acid recommended by Bruker Daltonics and many other researchers [39,52-55]. The obtained mass spectra were analyzed using flexAnalysis software. In a detailed examination of the mass spectra, the peak in region of $11,109 \mathrm{~m} / \mathrm{z}$ only in carbapenem-resistant K. pneumoniae KPCs (marked in red in the Figure 3) was detected. After analysis of K. pneumoniae susceptible to carbapenem, the same peak (marked in blue) was not observed. The presence of $11,109 \mathrm{~m} / \mathrm{z}$ peak in spectrum is representing a cleaved protein called pKpQIL_019. Subsequently, the presence of the plasmid pKpQIL, carrying the bla $a_{\mathrm{KPC}}$ gene in carbapenemresistant K. pneumoniae KPC, was detected by PCR. Lau et al. [56] was the first to describe the analysis and discovery of pKpQIL_019 protein by mass spectrometry in relation to carbapenem resistance in K. pneumoniae KPC. Presence of plasmid pKpQIL (GenBank Accession No. NC_014016.1), carrying the bla $a_{\mathrm{KPC}}$ gene responsible for carbapenem resistance in K. pneumoniae KPC, was confirmed by many researchers [56-59]. Lau et al. [56] used genetic analysis of $b l a_{\mathrm{KPC}}$ genes, isolation of plasmid pkpQIL, identification of cleavage product of hypothetical protein pKpQIL_019 using Q-TOF LC-MS, subsequent isolation of protein pKpQIL_019, sequencing by N-terminal Edman sequencing, and top-down and bottom-up proteomic analysis that the presence of the pKpQIL_019 hypothetical protein cleavage product in the mass spectrum. Hypothetical PKpQIL_019 protein gene was identified on plasmid pKpQIL next to the Tn4401 transposon between the transposase and resolvase genes [60,61]. The Tn4401 transposon has also been identified in other plasmids [56], specifically in the plasmid IncFIIK [62,63], IncN [64] and ColE [65,66], IncI2 [67,68], and IncX3 $[69,70]$. A thorough analysis of the pKpQIL sequences in the BLAST databases revealed that the p019 sequence responsible to produce the cleavage product of the hypothetical pKpQIL_019 protein was always identified in the bla $a_{\mathrm{KPC}}$ gene. However, it should be noted that PKpQIL_019 and bla $a_{\mathrm{KPC}}$ are genes located in two different mobile elements. The $b l a_{\mathrm{KPC}}$ gene is located in the Tn4401 transposon and pKpQIL_019 gene between the transposase and resolvase genes. This suggests that it is not entirely possible to associate pKpQIL_019 only with plasmid pKpQIL, but it can be identified as part of the less related plasmids IncFIIK (pKPN-101-IT) [62], IncI2 (pBK15692) [67], or IncX3 (pKPC-NY79) [69]. 


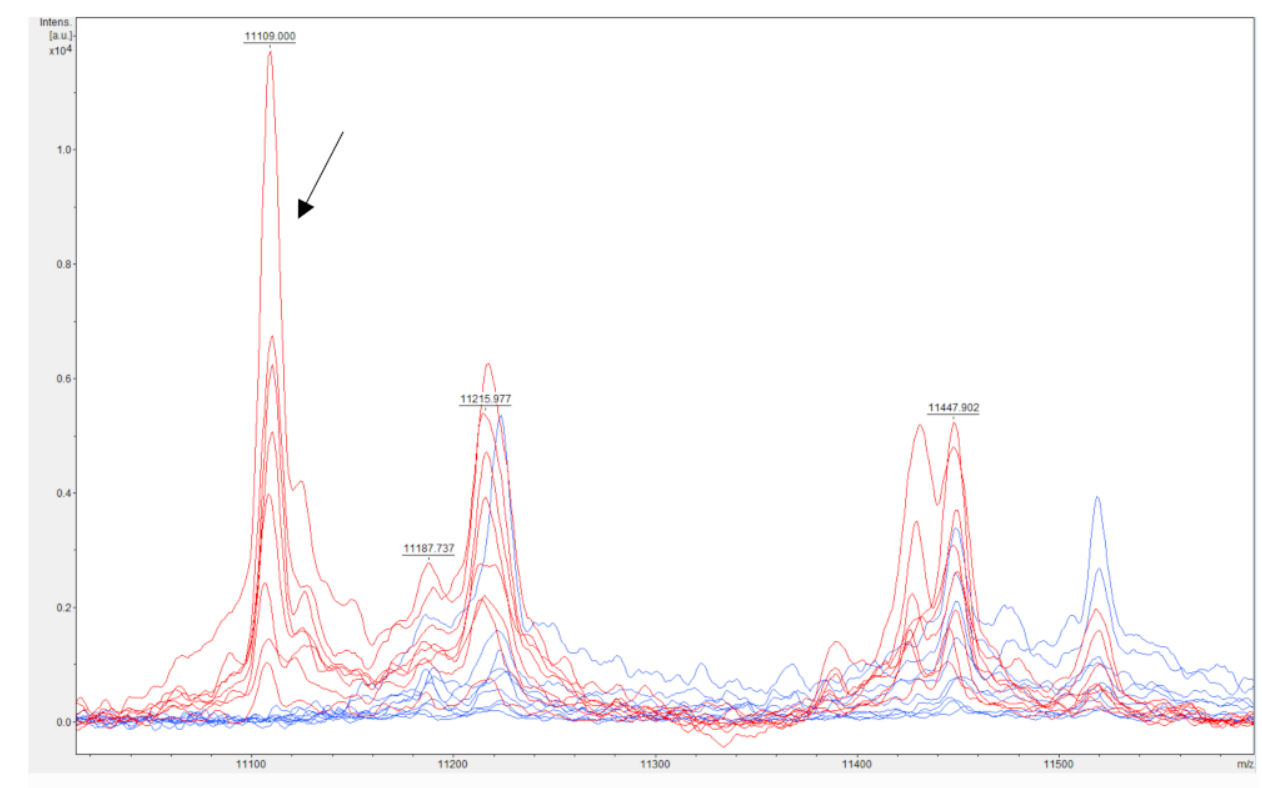

Figure 3. Identification of a peak (indicated by an arrow) associated with $b l a_{\mathrm{KPC}}$ resistance in Klebsiella pneumoniae KPC. MALDI-TOF MS spectrum of bla $a_{\mathrm{KPC}}$ positive (red) and negative (blue) K. pneumoniae.

Cordovana et al. [58] detected the $11,109 \mathrm{~m} / z$ peak in the mass spectrum of carbapenemresistant K. pneumoniae KPC, which is a cleavage product of the pKpQIL_019 hypothetical protein. They also verified the presence of the $b l a_{\mathrm{KPC}}$ gene and evaluated automated tracking of the 11,109 $\mathrm{m} / \mathrm{z}$ peak in numerous samples. Additionally, they tried to determine stability and repeatability of the $11,109 \mathrm{~m} / \mathrm{z}$ peak detection after culturing K. pneumoniae KPC on different nutrient media. Their results showed that the cultivation of K. pneumoniae on different nutrient media had no effect on the resulting mass spectrum measured by the MALDI-TOF MS system. The presence of the $b l a_{\mathrm{KPC}}$ gene was confirmed in all cases of the occurrence of a peak with $11,109 \mathrm{~m} / \mathrm{z}$ in the spectrum. Therewith, an automated system for evaluating a large number of samples was successful. As in our experiment, a peak with $11,109 \mathrm{~m} / \mathrm{z}$ in the spectrum was not detected by MALDI-TOF MS in any sample of susceptible K. pneumoniae. The 11,109 $\mathrm{m} / \mathrm{z}$ peak was identified solely in isolates with confirmed presence of the $b l a_{\mathrm{KPC}}$ gene. The $11,109 \mathrm{~m} / z$ carbapenem-resistant K. pneumoniae peak can be validated as a suitable marker of KPC producers and considered as appropriate for the detection of carbapenem-resistant $K$. pneumoniae $[56,58,59,62,67,69]$.

In our experiment, a peak with $11,109 \mathrm{~m} / z$ in the mass spectrum was expected, which is associated with a cleavage product of the protein expressed by the pkpQIL plasmid. The following peaks in the mass spectra of carbapenem-resistant K. pneumoniae KPC were detected: 5554, 5884, 6684, 7578, 8054, 8744, 10,883, 11,109, 11,767, 12,260, 13,004, 13,366, $14,445,15,139,16,109,17,489$, and 18,582 $\mathrm{m} / \mathrm{z}$. The peaks mentioned above were absent in the mass spectrum of K. pneumoniae susceptible to carbapenem (Figure 4A-D). The exact function of these proteins is not known from the available literature. It is a question for future analyses to document the differences found by mass spectrometry between KPC producers and non-productive strains of K. pneumoniae in detail. However, FigueroaEspinosa et al. [71] observed the predicted enzyme KPC-2 $\beta$-lactamase $(28,544 \mathrm{~m} / \mathrm{z})$ in the mass spectrum of KPC-2 production bacterial strains of the family Enterobacteriaceae, in particular K. pneumoniae, E. cloacae, E. coli, Serratia marcescens, and Citrobacter braakii. Additionally, they were able to detect KPC-2 $\beta$-lactamase in P. aeruginosa KPC-2. However, they found that the presence of the 11,109 $\mathrm{m} / \mathrm{z}$ peak occurs only in KPC-producing strains of K. pneumoniae and E. coli. Yoon et al. [72] observed significant differences in the range from 28,000 to $29,000 \mathrm{~m} / \mathrm{z}$ after mass spectra analysis of E. coli and K. pneumoniae strains with KPC-2, KPC-3, and KPC-4 types of $\beta$-lactamase resistance. On that basis, they were 
able to differentiate individual strains. With the help of statistical analyses of the detected mass spectra, they were able to introduce differentiation between KPC production strains by a direct intact method.
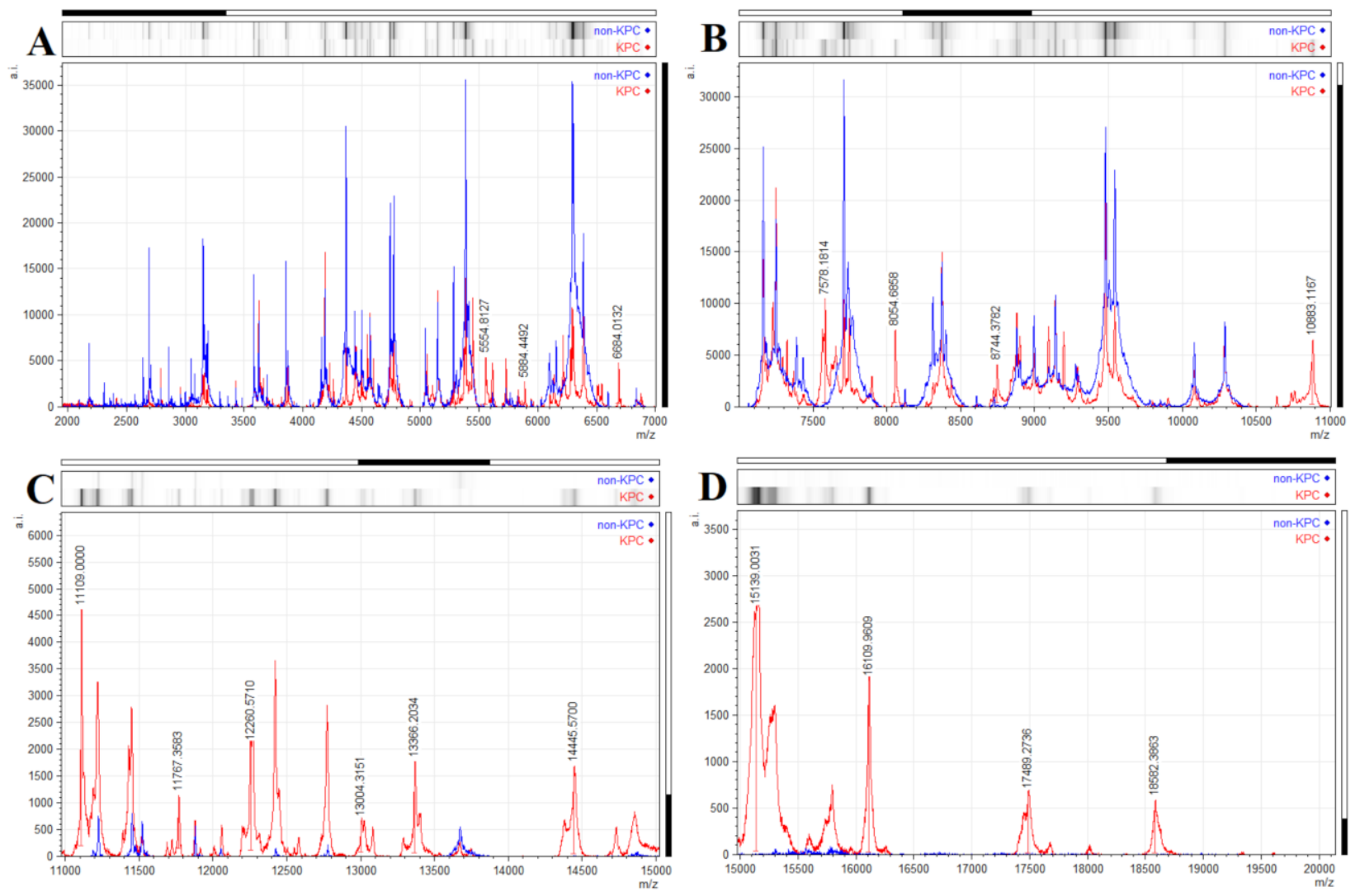

Figure 4. MALDI-TOF MS spectrum of susceptible and resistant K. pneumoniae (A) from 2000 to $7000 \mathrm{~m} / \mathrm{z}$, (B) from 7000 to $11,000 \mathrm{~m} / \mathrm{z}$, (C) from 11,000 to $15,000 \mathrm{~m} / \mathrm{z}$, and (D) from 15,000 to 20,000 m/z. Significantly unique peaks are indicated by an arrow (red-resistant K. pneumoniae KPC, blue-sensitive non-KPC K. pneumoniae).

\subsection{Identification Based on the Proteins Fingerprint Database}

The most direct and fastest form of carbapenem-resistant K. pneumoniae KPC identification may be performed by comparison of the entire mass spectrum. However, it requires the initial creation of a database of mass spectra for resistant and susceptible K. pneumoniae types. Standard mass spectrometry procedure was performed using the ethanol-formic acid-acetonitrile extraction method with overlapping and crystallization of the HCCA matrix [39,52-55]. Spectral maps were created from controlled mass spectra using flexAnalysis software. Using MALDI Biotyper OC software, analyzed spectra of resistant and sensitive K. pneumoniae were compared. Significant differences in the mass spectra were found. The identification tool in the MALDI Biotyper software was able to clearly identify resistant and susceptible species of K. pneumoniae (Figure 5) with a score higher than 2. Reproducibility reached $100 \%$ because all 92 measurements of KPC and non-KPC isolates were correctly identified (Fisher's exact test $p<0.001$ ). 


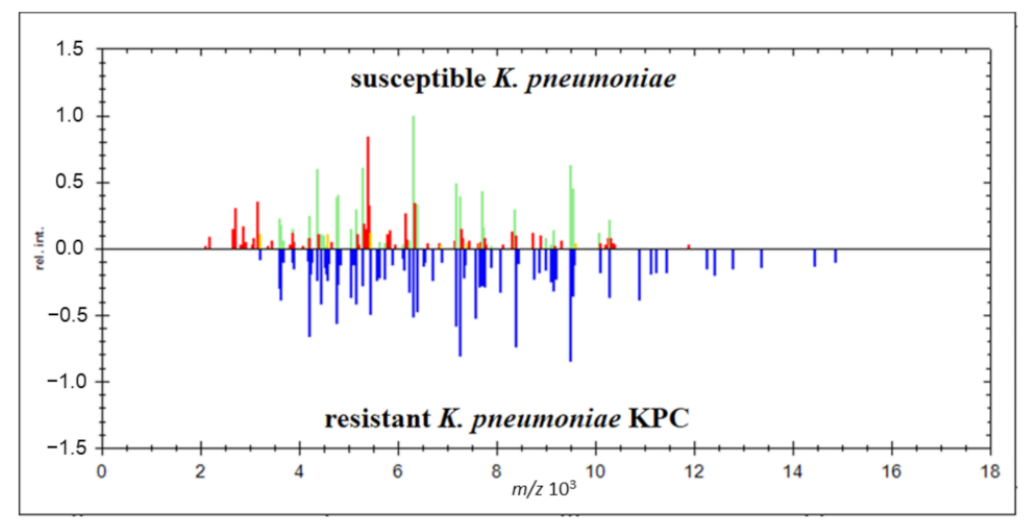

Figure 5. Comparison of mass spectra of susceptible and resistant K. pneumoniae.

We created a digital electrophoreogram for the discrimination of resistant and sensitive K. pneumoniae species stored in a locally created database of mass spectra. MALDI Biotyper subroutine was used to show the protein mass spectrum of resistant and sensitive K. pneumoniae isolates. The digital electrophoreogram clearly reads the higher density of detected proteins in the range from 10,000 to 20,000 m/z (Figure 6). The results suggested that carbapenem-resistant K. pneumoniae showed more peaks representing intact protein in the mass spectrum than susceptible K. pneumoniae.

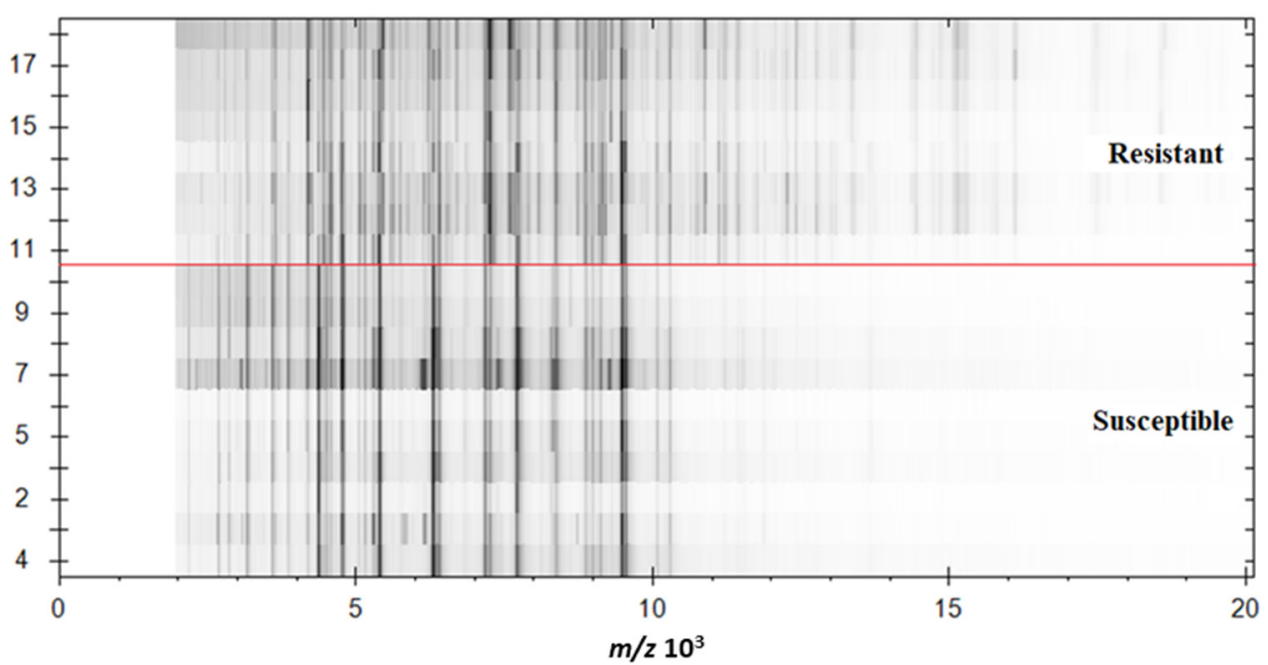

Figure 6. Digital electrophoreogram of resistant and susceptible bacteria K. pneumoniae (red line separates resistant from susceptible isolates). Measuring ranges from 2000 to 20,000 m/z.

We clearly defined the boundary between resistant and sensitive species of K. pneumoniae by statistical evaluation of mass spectra in the MALDI Biotyper program and subroutine for the creation of PCA dendrograms. The dendrogram showed the relationship between the analyzed K. pneumoniae samples based on the obtained mass spectra. The resulting analysis of the PCA dendrogram indicated that the resistant species are classified in the same cluster and the susceptible bacteria K. pneumoniae in the other cluster (Figure 7).

Statistical analysis for discrimination of KPC production strains, specifically KPC-2, KPC-3, and KPC-4 was used in work by Yoon et al. [72]. However, they did not analyze the entire mass spectrum obtained in the process of identifying K. pneumoniae. They focused only on a specific spectrum ranging from 18,000 to $19,000 \mathrm{~m} / \mathrm{z}$. The advantage of the technique used in this work is its very simple design. Moreover, it does not require focusing on a specific mass spectrum in KPC. It detects the entire mass spectrum in one step by the automated MALDI-TOF Biotyper system. However, it requires prior preparation of local mass spectra database for KPC resistant and susceptible strains of K. pneumoniae. 
The disadvantage of this technique is the identification of only KPC-producing and nonproductive strains of $K$. pneumoniae. We are not able to distinguish individual sub-types of KPC-2, KPC-3 or KPC-4 production strains of K. pneumoniae according to the total mass spectrum of K. pneumoniae, yet. The question of identifying KPC subtypes of K. pneumoniae probably lies on deciphering the unidentified differences in mass spectra, as we described in the chapter above. We were able to detect different mass spectra in KPC production and non-production strains of K. pneumoniae. Other more detailed studies need to be performed to confirm or refute our hypotheses.

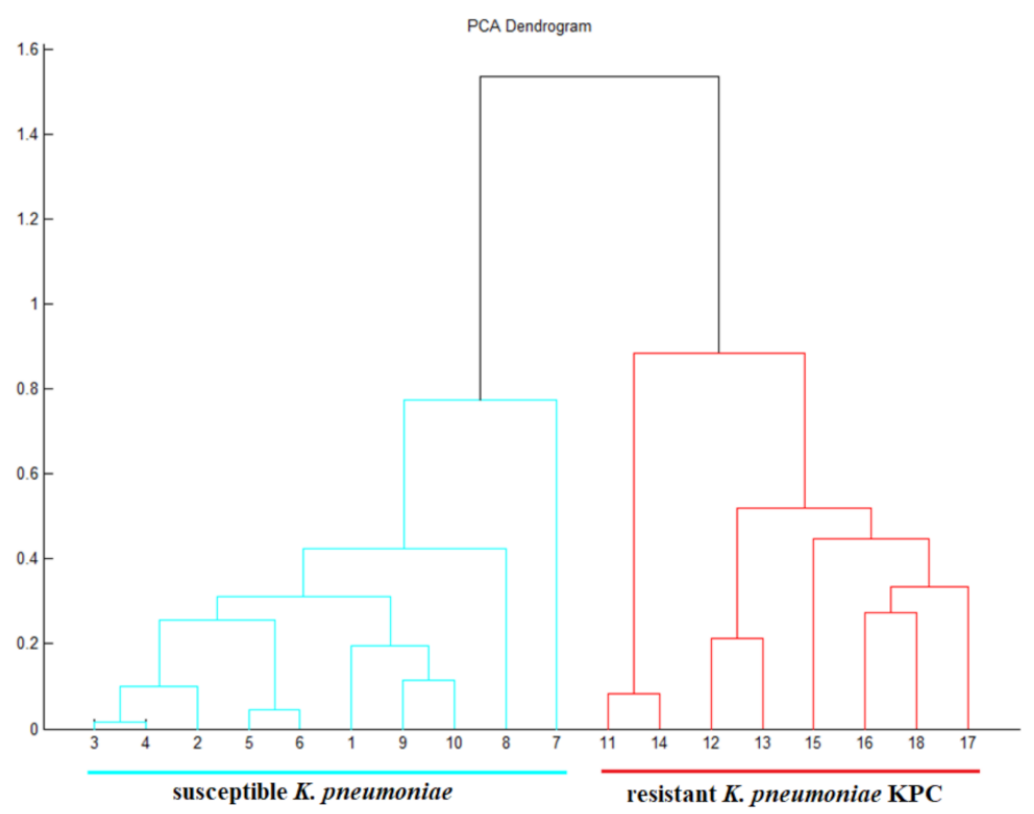

Figure 7. PCA dendrogram showing the relationship of individual samples of susceptible and resistant K. pneumoniae isolates based on measured mass spectra.

\section{Materials and Methods}

\subsection{Bacterial Isolates and Cultivation}

Eight clinical isolates of carbapenem-resistant Klebsiella pneumoniae (KPC) were obtained from the Slovak Academy of Science, Department of animal physiology, where $b l a_{\text {KPC }}$ gene was detected by PCR method, as described below. Ten Non-KPC isolates were selected from collection of K. pneumoniae isolates originated from different types of small fruits as raspberries $(n=2)$, blueberries $(n=4)$ and strawberries $(n=4)$ during years 2019 and 2020. Cultivation of both KPC and non-KPC strains was performed on MacConkey agar (HiMedia, Mumbai, India) for $24 \mathrm{~h}$ at $35 \pm 2{ }^{\circ} \mathrm{C}$. Pure cultures were obtained from the four-way streak plate method under the same conditions. Pure cultures of KPC and non-KPC strains were stored in sterile glycerol at $-80{ }^{\circ} \mathrm{C}$ until use.

\subsection{Identification of Klebsiella pneumoniae}

All strains used in this study were identified by MALDI-TOF MS using Microflex LT (Bruker Daltonics, Bremen, Germany) and Biotyper software (Bruker Daltonics, Bremen, Germany). The identification procedure was performed following Hleba et al. [73].

\subsection{Testing of Klebsiella pneumoniae Carbapenem Resistance}

\subsubsection{Antimicrobial Susceptibility Testing}

Firstly, disk diffusion (Kirby-Bauer) methodology according to EUCAST [74] guideline was performed. Meropenem (MEM) (Oxoid, Hampshire, England) with $10 \mu \mathrm{g}$ per disk was used in this study. The minimal inhibition concentration (MIC) was tested according to EUCAST [74]. For MIC Evaluator Strips Meropenem (0.002-32 $\mu \mathrm{g} / \mathrm{mL}$ ) (Oxoid, England) were used. Interpretation of MICs and zone diameter by EUCAST [75] was completed. 


\subsubsection{Carbapenemase-Production Screening}

Screening for carbapenemase production by EUCAST [74] was performed using disk diffusion (Kirby-Bauer) and minimal inhibition concentration methods where meropenem antibiotic was tested as described above [74]. In addition, combination disk testing was used according to EUCAST [16] with the algorithm for carbapenemase detection. Tablets (Rosco, Denmark) containing meropenem with various inhibitors (boronic acid, dipicolinic acid, and ethylenediaminetetraacetic acid) were tested against $K$. pneumoniae isolates. For the elimination of OXA-48 avibactam and AmpC hyperproduction with porin loss, a cloxacillin disk was used. The decision tree method was based on the algorithm for carbapenemase detection established by EUCAST [16]. In addition to the above-mentioned methods, the detection of carbapenem hydrolysis with MALDI-TOF mass spectrometry (Microflex LT, Bruker Daltonics, Bremen, Germany) was used.

\subsubsection{KPC Genetic Confirmation}

Genomic DNA from each isolate was extracted using EZ-10 Spin Column Bacterial Genomic DNA Miniprep Kit (Biobasic, Markham, ON, Canada). Presence and integrity of DNA was checked on agarose gel and its quantity was estimated using nanophotometer (Implen, Munich, Germany). Concentration of DNA was normalized to $20 \mathrm{ng} \cdot \mu \mathrm{L}^{-1}$.

The presence or absence of bla $a_{\mathrm{KPC}}$ gene was confirmed by PCR using specific primers [76] which amplify complete sequence of $b l a_{\mathrm{KPC}}$ gene family. Thirty $\mu \mathrm{L}$ of PCR mixture contained Dream Taq Green buffer $1 \times, 2 \mathrm{mM}$ of DNTP mix, $1 \mathrm{U}$ of DreamTaq polymerase (All chemicals from Thermo, Waltham, MA, USA), $0.5 \mu \mathrm{M}$ of primer Uni-KPC-F (5'-ATGTCACTGTATCGCCGTCT-3') $0.5 \mu \mathrm{M}$ of primer Uni-KPC-F ( $5^{\prime}$-TTACTGCCCGTTGACGCCC- $\left.3^{\prime}\right)$, and $1 \mu \mathrm{L}$ of extracted DNA.

The amplification was performed using MJ Mini Thermal Cycler (Biorad, Hercules, CA, USA) with the following settings: $95^{\circ} \mathrm{C}$ for $3 \mathrm{~min}$ for initial denaturation, followed by 35 cycles of $95^{\circ} \mathrm{C}$ for $30 \mathrm{~s}, 55^{\circ} \mathrm{C}$ for $30 \mathrm{~s}$ and $72^{\circ} \mathrm{C}$ for $1 \mathrm{~min}$, and a final extension step at $72{ }^{\circ} \mathrm{C}$ for $5 \mathrm{~min}$.

Presence of PCR product was detected using agarose gel electrophoresis $(1.5 \%$ gel, $1 \mathrm{X}$ TAE buffer, $5 \mu \mathrm{L}$ DNA loaded). Migration speed was compared to $100 \mathrm{bp}$ plus ladder (Thermo, Waltham, MA, USA) after visualization with ethidium bromide. Isolate was scored as positive for $b l a_{\mathrm{KPC}}$ gene if PCR product of approximately $900 \mathrm{bp}$ was detected.

\subsubsection{Indirect Detection of Enzymatic Hydrolysis}

The main objective of the first procedure was to indirectly detect enzymatic hydrolysis of $\beta$-lactams antibiotic meropenem. The principle is based on the hydrolysis of $\beta$-lactam antibiotics by $\beta$-lactamases produced by resistant carbapenem-producing K. pneumoniae (KPC). Subsequently, degradation products of antibiotic were monitored by MALDI-TOF mass spectrometry. Hydrolysis of meropenem using sodium hydroxide was used as a comparative model. Peaks of intact meropenem as well as degradation products were detected by MALDI-TOF and compared to that produced by KPC K. pneumonia. Following equation (Figure 8) served as a template of hydrolysis:

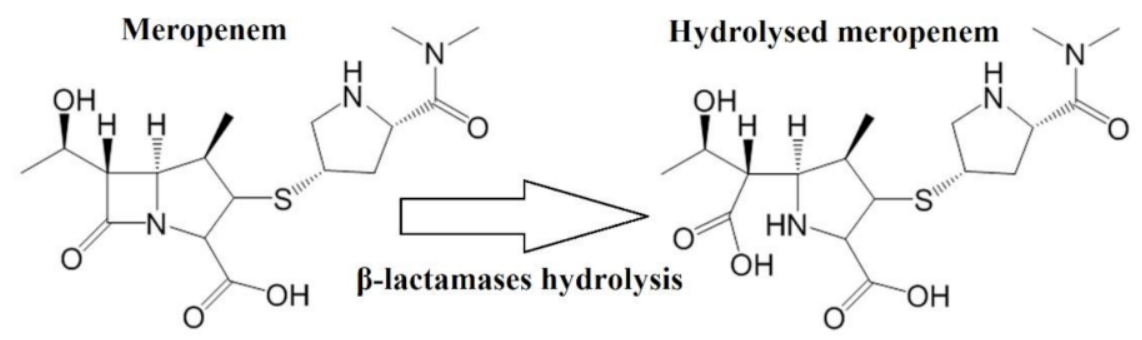

Figure 8. Hydrolysis of meropenem by $\beta$-lactamases produced by resistant bacteria. 


\subsubsection{MALDI-TOF MS Analysis of Meropenem}

In this experiment, commercially available meropenem containing sodium carbonate (meropenem, 500 mg, Hospira UK Limited, Maidenhead, United Kingdom) was used. Different concentrations of meropenem diluted in $20 \mathrm{mM}$ Tris-HCl buffer, $\mathrm{pH} 7$ (Sigma Aldrich, Taufkirchen, Germany) were used for detection by MALDI-TOF MS. Meropenem was diluted in pure MS water 99.9\% (Sigma Aldrich, Germany) and pure MS ethanol 99.8\% (Sigma Aldrich, Germany) for observation. As a matrix, $2.5 \mathrm{mg} \alpha$-cyano-4-hydroxycinnamic acid (HCCA) and $2.5 \mathrm{mg}$ dihydroxybenzoic acid (DHB) was used and diluted in $250 \mathrm{~mL}$ organic solvent (OR). The organic solvent contained $500 \mathrm{~mL}$ of $100 \%$ acetonitrile, $475 \mathrm{~mL}$ of distilled water, and $25 \mathrm{~mL}$ of $100 \%$ trifluoroacetic acid (all chemicals were obtained from Sigma Aldrich, Taufkirchen, Germany in MS purity). One microliter of the samples (meropenem in different concentrations diluted in Tris- $\mathrm{HCl}$ ) was applied on the target plate (Bruker Daltonics, Germany, MSP Target) and allowed to dry at room temperature. Subsequently, the samples were covered with a $\alpha$-cyano-4-hydroxycinnamic acid (HCCA) matrix. Mass spectra were acquired using Microflex LT mass spectrometer with the FlexControl 3.4 software (Bruker Daltonics, Bremen, Germany) operating in the positive linear ion mode between 300 and $500 \mathrm{~m} / z$. Microflex LT using FlexControl software was set in following parameters: ion source $1: 20 \mathrm{kV}$, ion source $2: 16.7 \mathrm{kV}$, lens:7 kV, pulsed ion extraction: $170 \mathrm{~ns}$, detection gain: $3.0 \times$, electronic gain: regular, mode: low range, mass range selection: low range, laser frequency: $60 \mathrm{~Hz}$, digitizer trigger level: $2500 \mathrm{mV}$, laser attenuator: $24 \%$, laser attenuator: $30 \%$, laser range: $70-90 \%$. Mass spectra by 500 laser shots were measured randomly. The concentration of meropenem was $10 \mu \mathrm{g} / \mathrm{mL}$. Meropenem was degraded by $100 \mathrm{mM} \mathrm{NaOH}$ and diluted in $20 \mathrm{mM}$ Tris- $\mathrm{HCl}$ to a final concentration of $10 \mathrm{mM}$.

\subsubsection{Ampicillin and Meropenem Hydrolysis Assay}

Purified K. pneumoniae bacterial strains were incubated overnight in Mueller-Hinton broth (Biolife, Milano, Italy) to increase the density. One milliliter of high-density inoculum, $4 \mathrm{McF}^{\circ}$, was pipetted into the microtube and centrifuged at the maximum speed $(13,000 \mathrm{rpm})$. Pellet was purified using physiological solution that was prepared in $1 \mathrm{~mL}$ of $20 \mathrm{mM}$ Tris- $\mathrm{HCl}$ buffer ( $\mathrm{pH}$ 7) with $150 \mathrm{mM} \mathrm{NaCl}$ and then centrifuged at the maximum speed for $3 \mathrm{~min}$. The supernatant was discarded. A $50 \mathrm{~mL}$ of $50 \%$ meropenem diluted in $20 \mathrm{mM}$ Tris- $\mathrm{HCl}$ buffer ( $\mathrm{pH}$ 7) was added to the pellet and mixed by pipette. Afterwards, the resulting mixture was incubated at $35 \pm 2{ }^{\circ} \mathrm{C}$ for $3 \mathrm{~h}$. After $3 \mathrm{~h}$ of incubation, the mixture was centrifuged at the same conditions and $1 \mathrm{~mL}$ of supernatant was analyzed by MALDI TOF mass spectrometry.

\subsubsection{Analysis of Spectra}

For spectrum analysis, flexAnalysis 3.4 software (Bruker Daltonics, Bremen, Germany) was used. Peaks were detected by Centroid detection algorithm with a signal-to-noise threshold of 1 , a relative intensity threshold of $0 \%$, a minimum intensity threshold of 0 , a peak width of $0.2 \mathrm{~m} / \mathrm{z}$, a height of $80 \%$, a TopHat baseline subtraction, smoothing with the Savitzky-Golay algorithm, with $0.2 \mathrm{~m} / z$ width and a one cycle. Theoretical peaks of meropenem, degradation products, and their sodium salts were compared with our detected masses with a $\pm 0.6 \mathrm{~m} / \mathrm{z}$.

\subsubsection{Calibration of MALDI-TOF MS}

Calibration of MALDI-TOF MS in this experiment was performed using meropenem, and its degradation products and sodium salts from artificial hydrolysis of meropenem by $\mathrm{NaOH}$.

\subsubsection{Identification of $b l a_{\mathrm{KPC}}$ Accompanying Peak with $11,109 \mathrm{Da}$}

The goal was the identification of accompanying peak with 11,109 Da in the mass spectrum of K. pneumoniae (KPC), which represents the cleaved protein (pKpQIL_p019) 
expressed by pKpQIL plasmid. Cleaved protein entitled pKpQIL_p019 is accompanying protein in the expression process of genes of plasmids $\mathrm{pKpQIL}$ in carbapenem-resistant K. pneumoniae KPC [56].

\subsubsection{MALDI-TOF MS Samples Preparing}

Intact proteins of K. pneumoniae were obtained using standard intact protein extraction procedure established by Bruker Daltonics for identification of microorganisms. Purified overnight cultures were transferred as bacterial colonies to $50 \mu \mathrm{L}$ solution in microtube containing $25 \mu \mathrm{L}$ of acetonitrile and $25 \mu \mathrm{L}$ of formic acid for membrane disruption and obtaining of intact proteins. The resulting suspensions were homogenized by vortexing for cell membrane disintegration. Afterwards, the samples were centrifuged at the maximum speed (13,000 rpm). One $\mu \mathrm{L}$ of supernatant was transferred by pipetting to 96 MALDI-TOF Stainless steel plate (Bruker Daltonics, Bremen, Germany). All samples were overlaid with $1 \mu \mathrm{L}$ of $\alpha$-cyano-4-hydroxycinnamic acid (HCCA), which was prepared as previously described. The samples placed on a MALDI-TOF Stainless steel plate were dried at room temperature for crystallization with the matrix.

\subsubsection{MALDI-TOF MS Spectrum Obtaining}

Mass spectra of K. pneumoniae were obtained by MALDI-TOF MS Microflex LT (Bruker Daltonics, Germany) in linear positive mode with a $337 \mathrm{~nm}$ pulsed laser. All other settings were performed by Bruker Daltonics standard procedure, which is used for micro-organisms identification in the range from $2 \mathrm{kDa}$ to $20 \mathrm{kDa}$. Mass spectra were obtained using FlexControl software ver. 3.4 (Bruker Daltonics, Bremen, Germany).

\subsubsection{Mass Spectra Analysis}

Mass spectra obtained from all K. pneumoniae isolates were analyzed by flexAnalysis software ver. 3.4 (Bruker Daltonics, Bremen, Germany). In this procedure, we focused primarily on the area of the mass spectrum about $11,109 \mathrm{Da}$, where the accompanying peak should be occurring. In addition, we focused on all differences between resistant and susceptible K. pneumoniae along the entire mass spectrum. Determined differences in mass spectra were used for the following differentiation of resistant and susceptible K. pneumoniae based on the whole mass spectra saved in our local proteins fingerprint database.

\subsubsection{Identification Based on the Proteins Fingerprint Database}

The last procedure was to create of proteins fingerprint local database. Klebsiella pneumoniae local database was created from the pure, high-quality, and strong intensity (intensity $>1 \times 10^{3}$ arbitrary units-a.u.) mass spectra obtained from a previously described experiment where an accompanying peak with 11,109 Da was acquired. Database included mass spectra of resistant and susceptible K. pneumoniae and it was used to compare with the further tested K. pneumoniae isolates.

\subsubsection{Analysis of Mass Spectra}

Mass spectra of all K. pneumoniae isolates were analyzed by flexAnalysis version 3.4. We monitored the spectrum from $2 \mathrm{kDa}$ to $20 \mathrm{kDa}$. Priority was the purity and quality of mass spectra observed by flexAnalysis. We also focused on the intensity of mass spectra, which was at a minimal value of $10^{4}$. All mass spectra were obtained from minimal 8 replications with 500 laser shots for each sample. The reproducibility of mass spectra was also considered. Obtained mass spectra were transferred to the local database into the MALDI Biotyper OC software version 3.1. Graphical representations of obtained $K$. pneumoniae KPC and non-KPC whole mass spectra were made using MALDI Biotyper OC software ver. 3.1 in the form of an electrophoreogram. mMass software [77] was used for whole mass spectra and differences between KPC and non-KPC spectra of K. pneumoniae. The crude spectra were converted from Bruker *.lid files using CompassXport software (Bruker Daltonics, Germany) and forwarded to mMass for processing. All spectra were 
aligned to the baseline and smoothed by Savitzky-Golay with $0.3 \mathrm{~m} / \mathrm{z}$ and one cycle. The resulting spectra were averaged for better interpretation of the results.

\subsubsection{Creation of Local K. pneumoniae Database and Verification of Reproducibility}

Klebsiella pneumoniae local database was created by the same protocol as in our previous study [29]. Reproducibility was verified using a blind test where random isolates of non-KPC and KPC K. pneumoniae were chosen and re-analyzed. In four independent time-points, together 28 analyses of KPC isolates and 64 analyses of non-KPC isolates were performed. Analysis was counted as reproducible when MALDI Biotyper OC software correctly identified a sample using our own local database of spectra. Statistical confirmation was obtained by Fisher's exact test in Statgraphics XV (Statgraphics Technologies, Inc., The Plains, VA, USA).

\section{Conclusions}

In general conclusion, results confirmed that MALDI-TOF MS is an adequate technique for discrimination of carbapenemase-producing K. pneumoniae and non-KPC strain. It should be noted at the outset that all used procedures required purified fresh living bacterial colonies. Comparing of all the procedures used in this experiment led to the following conclusions: The procedure based on observing of hydrolyzed meropenem degradation products required pure bacterial colonies to be cultured overnight, their cultivation with antibiotic, specific set-up of MALDI-TOF for small molecule acquisition ranging from 300 to $500 \mathrm{~m} / \mathrm{z}$, and the comparison and observation of acquired mass spectrum by post processing mass spectra software. In this case, intact bacterial proteins were not isolated. In addition, the procedure required skilled and experienced technicians. The procedure based on the detection of specific protein biomarker with 11,109 $\mathrm{Da}$, which represent cleaved protein pKpQIL_p019 expressed by pKpQIL plasmid carrying the $b l a_{\mathrm{KPC}}$ gene, required less skilled and experienced technicians, because it is not necessary to set up equipment. It is quite sufficient if the manufacturer's instructions are followed. Intact proteins can be isolated by standardized procedures and after obtaining the whole mass spectrum, it can be evaluated by post processing mass spectrum software. The operator can easily find the specific peak with 11,109 Da. The last used procedure, based on comparing the whole mass spectrum of K. pneumoniae isolates with whole mass spectra saved in created local protein database, is the most rapid and the simplest procedure. This method can also be performed by a less experienced MALDI-TOF MS operator, who is familiar with the basics of identification of microorganisms using mass spectrometry. However, this method required previous confirmation by several methods for detection of carbapenemase-production in K. pneumoniae described in this study. The fastest way to identify carbapenem-resistant K. pneumoniae (KPC) is a direct identification by the whole mass spectrum with the previous database creation. The limitation lies in the creation of your own database, which is not available yet. Moreover, MALDI-TOF MS requires a large initial investment. However, subsequent analyses are very simple, fast, and inexpensive.

Author Contributions: Conceptualization, L.H.; methodology, L.H., J.M. and M.H.; software, L.H. and J.M.; validation, L.H., M.H. and A.K.; formal analysis, J.Č. and A.K.; investigation, L.H., M.H., A.K., J.Č. and J.M.; resources, J.M and L.H.; data curation, L.H. and J.M.; writing-original draft preparation, L.H., M.H., J.Č.; writing—review and editing, all authors; visualization, L.H.; supervision, L.H., A.K.; project administration, J.M.; funding acquisition, J.M. All authors have read and agreed to the published version of the manuscript.

Funding: This research was financially supported by project of Ministry of Education, Science, Research and Sport of the Slovak Republic, grant no. VEGA 1/0661/19 "Plant microbiome and safe food".

Data Availability Statement: All data are available upon request from the corresponding author.

Conflicts of Interest: The authors declare no conflict of interest. 


\section{References}

1. Arnold, R.S.; Thom, K.A.; Sharma, S.; Phillips, M.; Kristie Johnson, J.; Morgan, D.J. Emergence of Klebsiella Pneumoniae Carbapenemase-Producing Bacteria. South. Med. J. 2011, 104, 40-45. [CrossRef] [PubMed]

2. Kim, H.S.; Chon, J.W.; Kim, Y.J.; Kim, D.H.; Kim, M.S.; Seo, K.H. Prevalence and Characterization of Extended-Spectrum- $\beta$ Lactamase-Producing Escherichia Coli and Klebsiella Pneumoniae in Ready-to-Eat Vegetables. Int. J. Food Microbiol. 2015, 207, 83-86. [CrossRef] [PubMed]

3. Romyasamit, C.; Sornsenee, P.; Chimplee, S.; Yuwalaksanakun, S.; Wongprot, D.; Saengsuwan, P. Prevalence and Characterization of Extended-Spectrum -Lactamaseproducing Escherichia Coli and Klebsiella Pneumoniae Isolated from Raw Vegetables Retailed in Southern Thailand. PeerJ 2021, 9, e11787. [CrossRef]

4. Zekar, F.M.; Granier, S.A.; Touati, A.; Millemann, Y. Occurrence of Third-Generation Cephalosporins-Resistant Klebsiella Pneumoniae in Fresh Fruits and Vegetables Purchased at Markets in Algeria. Microb. Drug Resist. 2020, 26. [CrossRef]

5. Struve, C.; Krogfelt, K.A. Pathogenic Potential of Environmental Klebsiella Pneumoniae Isolates. Environ. Microbiol. 2004, 6, 353-359. [CrossRef] [PubMed]

6. Siu, L.K.; Yeh, K.M.; Lin, J.C.; Fung, C.P.; Chang, F.Y. Klebsiella Pneumoniae Liver Abscess: A New Invasive Syndrome. Lancet Infect. Dis. 2012, 12, 881-887. [CrossRef]

7. Ghaith, D.M.; Zafer, M.M.; Said, H.M.; Elanwary, S.; Elsaban, S.; Al-Agamy, M.H.; Bohol, M.F.F.; Bendary, M.M.; Al-Qahtani, A.; Al-Ahdal, M.N. Genetic Diversity of Carbapenem-Resistant Klebsiella Pneumoniae Causing Neonatal Sepsis in Intensive Care Unit, Cairo, Egypt. Eur. J. Clin. Microbiol. Infect. Dis. 2020, 39, 583-591. [CrossRef] [PubMed]

8. Chen, L.F.; Anderson, D.J.; Paterson, D.L. Overview of the Epidemiology and the Threat of Klebsiella Pneumoniae Carbapenemases (KPC) Resistance. Infect. Drug Resist. 2012, 5, 133-141. [CrossRef] [PubMed]

9. Coulson, R.A.A.; Frere, F.; Ghuysen, J.; Joris, B.; Forsman, M.; Levesque, R.; Tiraby, G.; Waley, S. A Standard Numbering Scheme for the Class A Beta-Lactamases. Biochem. J. 1991, 276, 1145.

10. Doern, C.D.; Michael Dunne, W.; Burnham, C.A.D. Detection of Klebsiella Pneumoniae Carbapenemase (KPC) Production in Non-Klebsiella Pneumoniae Enterobacteriaceae Isolates by Use of the Phoenix, Vitek 2, and Disk Diffusion Methods. J. Clin. Microbiol. 2011, 49, 1143-1147. [CrossRef] [PubMed]

11. Giske, C.G.; Gezelius, L.; Samuelsen, M.; Warner, M.; Sundsfjord, A.; Woodford, N. A Sensitive and Specific Phenotypic Assay for Detection of Metallo- $\beta$-Lactamases and KPC in Klebsiella Pneumoniae with the Use of Meropenem Disks Supplemented with Aminophenylboronic Acid, Dipicolinic Acid and Cloxacillin. Clin. Microbiol. Infect. 2011, 17, 552-556. [CrossRef] [PubMed]

12. Dortet, L.; Poirel, L.; Nordmann, P. Rapid Identification of Carbapenemase Types in Enterobacteriaceae and Pseudomonas Spp. by Using a Biochemical Test. Antimicrob. Agents Chemother. 2012, 56, 6437-6440. [CrossRef] [PubMed]

13. van der Zwaluw, K.; de Haan, A.; Pluister, G.N.; Bootsma, H.J.; de Neeling, A.J.; Schouls, L.M. The Carbapenem Inactivation Method (CIM), a Simple and Low-Cost Alternative for the Carba NP Test to Assess Phenotypic Carbapenemase Activity in Gram-Negative Rods. PLoS ONE 2015, 10, e0123690. [CrossRef] [PubMed]

14. Hrabák, J.; Študentová, V.; Walková, R.; Žemličková, H.; Jakubů, V.; Chudáčková, E.; Gniadkowski, M.; Pfeifer, Y.; Perry, J.D.; Wilkinson, K.; et al. Detection of NDM-1, VIM-1, KPC, OXA-48, and OXA-162 Carbapenemases by Matrix-Assisted Laser Desorption Ionization-Time of Flight Mass Spectrometry. J. Clin. Microbiol. 2012, 50, 2441-2443. [CrossRef]

15. Pasteran, F.; Denorme, L.; Ote, I.; Gomez, S.; de Belder, D.; Glupczynski, Y.; Bogaerts, P.; Ghiglione, B.; Power, P.; Mertens, P.; et al. Rapid Identification of OXA-48 and OXA-163 Subfamilies in Carbapenem-Resistant Gram-Negative Bacilli with a Novel Immunochromatographic Lateral Flow Assay. J. Clin. Microbiol. 2016, 54, 2832-2836. [CrossRef] [PubMed]

16. Giske, C.G.; Martinez-Martinez, L.; Cantón Spain, R.; Stefani, S.; Skov, R.; Glupczynski, Y.; Nordmann, P.; Wootton, M.; Miriagou, V.; Skov Simonsen, G. EUCAST Guidelines for Detection of Resistance Mechanisms and Specific Resistances of Clinical and/or Epidemiological Importance. Eur. Comm. Antimicrob. Susceptibility Test. 2017, 11, 1423.

17. Yaman, G.; Akyar, I.; Can, S. Evaluation of the MALDI TOF-MS Method for Identification of Candida Strains Isolated from Blood Cultures. Diagn. Microbiol. Infect. Dis. 2012, 73, 65-67. [CrossRef]

18. Karger, A. Current Developments to Use Linear MALDI-TOF Spectra for the Identification and Typing of Bacteria and the Characterization of Other Cells/Organisms Related to Infectious Diseases. Proteom.-Clin. Appl. 2016, 10, 982-993. [CrossRef] [PubMed]

19. Johnson, J.S.; Spakowicz, D.J.; Hong, B.Y.; Petersen, L.M.; Demkowicz, P.; Chen, L.; Leopold, S.R.; Hanson, B.M.; Agresta, H.O.; Gerstein, M.; et al. Evaluation of 16S RRNA Gene Sequencing for Species and Strain-Level Microbiome Analysis. Nat. Commun. 2019, 10, 5029. [CrossRef]

20. Homolka, S.; Projahn, M.; Feuerriegel, S.; Ubben, T.; Diel, R.; Nübel, U.; Niemann, S. High Resolution Discrimination of Clinical Mycobacterium Tuberculosis Complex Strains Based on Single Nucleotide Polymorphisms. PLoS ONE 2012, 7, e39855. [CrossRef] [PubMed]

21. Leonard, S.R.; Mammel, M.K.; Lacher, D.W.; Elkins, C.A. Strain-Level Discrimination of Shiga Toxin-Producing Escherichia Coli in Spinach Using Metagenomic Sequencing. PLoS ONE 2016, 11, e0167870. [CrossRef]

22. Quainoo, S.; Coolen, J.P.M.; van Hijum, S.A.F.T.; Huynen, M.A.; Melchers, W.J.G.; van Schaik, W.; Wertheim, H.F.L. WholeGenome Sequencing of Bacterial Pathogens: The Future of Nosocomial Outbreak Analysis. Clin. Microbiol. Rev. 2017, $30,112$. [CrossRef] [PubMed] 
23. Jolley, K.A.; Bliss, C.M.; Bennett, J.S.; Bratcher, H.B.; Brehony, C.; Colles, F.M.; Wimalarathna, H.; Harrison, O.B.; Sheppard, S.K.; Cody, A.J.; et al. Ribosomal Multilocus Sequence Typing: Universal Characterization of Bacteria from Domain to Strain. Microbiology 2012, 158, 1005-1015. [CrossRef] [PubMed]

24. Manzoor, S.; Moncayo, S.; Navarro-Villoslada, F.; Ayala, J.A.; Izquierdo-Hornillos, R.; de Villena, F.J.M.; Caceres, J.O. Rapid Identification and Discrimination of Bacterial Strains by Laser Induced Breakdown Spectroscopy and Neural Networks. Talanta 2014, 121, 65-70. [CrossRef]

25. Alamer, S.; Eissa, S.; Chinnappan, R.; Herron, P.; Zourob, M. Rapid Colorimetric Lactoferrin-Based Sandwich Immunoassay on Cotton Swabs for the Detection of Foodborne Pathogenic Bacteria. Talanta 2018, 185, 275-280. [CrossRef] [PubMed]

26. Vidic, J.; Vizzini, P.; Manzano, M.; Kavanaugh, D.; Ramarao, N.; Zivkovic, M.; Radonic, V.; Knezevic, N.; Giouroudi, I.; Gadjanski, I. Point-of-Need DNA Testing for Detection of Foodborne Pathogenic Bacteria. Sensors 2019, 19, 1100. [CrossRef] [PubMed]

27. Kántor, A.; Hutková, J.; Petrová, J.; Hleba, L.; Kačániová, M. Antimicrobial Activity of Pulcherrimin Pigment Produced by Metschnikowia Pulcherrima against Various Yeast Species. J. Microbiol. Biotechnol. Food Sci. 2016, 5, 282-285. [CrossRef]

28. Hleba, L.; Kmet', V.; Tóth, T.; Kačániová, M. Resistance in Bacteria and Indirect Beta-Lactamase Detection in E. Coli Isolated from Culex Pipiens Detected by Matrix-Assisted Laser Desorption Ionization Time of Flight Mass Spectrometry. J. Environ. Sci. Health-Part B Pestic. Food Contam. Agric. Wastes 2017, 52, 64-69. [CrossRef] [PubMed]

29. Hleba, L.; Charousova, I.; Cisarova, M.; Kovacik, A.; Kormanec, J.; Medo, J.; Bozik, M.; Javorekova, S. Rapid Identification of Streptomyces Tetracycline Producers by MALDI-TOF Mass Spectrometry. J. Environ. Sci. Health-Part A Toxic/Hazard. Subst. Environ. Eng. 2018, 53, 1083-1093. [CrossRef] [PubMed]

30. Li, Y.; Shan, M.; Zhu, Z.; Mao, X.; Yan, M.; Chen, Y.; Zhu, Q.; Li, H.; Gu, B. Application of MALDI-TOF MS to Rapid Identification of Anaerobic Bacteria. BMC Infect. Dis. 2019, 19, 4584. [CrossRef] [PubMed]

31. Hou, T.Y.; Chiang-Ni, C.; Teng, S.H. Current Status of MALDI-TOF Mass Spectrometry in Clinical Microbiology. J. Food Drug Anal. 2019, 27, 404-414. [CrossRef]

32. Siegrist, T.J.; Anderson, P.D.; Huen, W.H.; Kleinheinz, G.T.; McDermott, C.M.; Sandrin, T.R. Discrimination and Characterization of Environmental Strains of Escherichia Coli by Matrix-Assisted Laser Desorption/Ionization Time-of-Flight Mass Spectrometry (MALDI-TOF-MS). J. Microbiol. Methods 2007, 68, 554-562. [CrossRef] [PubMed]

33. Hettick, J.M.; Kashon, M.L.; Slaven, J.E.; Ma, Y.; Simpson, J.P.; Siegel, P.D.; Mazurek, G.N.; Weissman, D.N. Discrimination of Intact Mycobacteria at the Strain Level: A Combined MALDI-TOF MS and Biostatistical Analysis. Proteomics 2006, 6, $6416-6425$. [CrossRef]

34. Vargha, M.; Takáts, Z.; Konopka, A.; Nakatsu, C.H. Optimization of MALDI-TOF MS for Strain Level Differentiation of Arthrobacter Isolates. J. Microbiol. Methods 2006, 66, 399-409. [CrossRef] [PubMed]

35. Lasch, P.; Fleige, C.; Stämmler, M.; Layer, F.; Nübel, U.; Witte, W.; Werner, G. Insufficient Discriminatory Power of MALDI-TOF Mass Spectrometry for Typing of Enterococcus Faecium and Staphylococcus Aureus Isolates. J. Microbiol. Methods 2014, 100, 58-69. [CrossRef]

36. Takahashi, N.; Nagai, S.; Fujita, A.; Ido, Y.; Kato, K.; Saito, A.; Moriya, Y.; Tomimatsu, Y.; Kaneta, N.; Tsujimoto, Y.; et al. Discrimination of Psychrotolerant Bacillus Cereus Group Based on MALDI-TOF MS Analysis of Ribosomal Subunit Proteins. Food Microbiol. 2020, 91, 103542. [CrossRef]

37. Novais, Â.; Sousa, C.; de Dios Caballero, J.; Fernandez-Olmos, A.; Lopes, J.; Ramos, H.; Coque, T.M.; Cantón, R.; Peixe, L. MALDI-TOF Mass Spectrometry as a Tool for the Discrimination of High-Risk Escherichia Coli Clones from Phylogenetic Groups B2 (ST131) and D (ST69, ST405, ST393). Eur. J. Clin. Microbiol. Infect. Dis. 2014, 33, 1391-1399. [CrossRef] [PubMed]

38. Nagy, E.; Urbán, E.; Becker, S.; Kostrzewa, M.; Vörös, A.; Hunyadkürti, J.; Nagy, I. MALDI-TOF MS Fingerprinting Facilitates Rapid Discrimination of Phylotypes I, II and III of Propionibacterium Acnes. Anaerobe 2013, 20, 20-26. [CrossRef] [PubMed]

39. Sakarikou, C.; Ciotti, M.; Dolfa, C.; Angeletti, S.; Favalli, C. Rapid Detection of Carbapenemase-Producing Klebsiella Pneumoniae Strains Derived from Blood Cultures by Matrix-Assisted Laser Desorption Ionization-Time of Flight Mass Spectrometry (MALDITOF MS). BMC Microbiol. 2017, 17, 9523. [CrossRef] [PubMed]

40. Yu, J.; Liu, J.; Li, Y.; Yu, J.; Zhu, W.; Liu, Y.; Shen, L. Rapid Detection of Carbapenemase Activity of Enterobacteriaceae Isolated from Positive Blood Cultures by MALDI-TOF MS. Ann. Clin. Microbiol. Antimicrob. 2018, 17, 22. [CrossRef] [PubMed]

41. Wang, L.; Han, C.; Sui, W.; Wang, M.; Lu, X. MALDI-TOF MS Applied to Indirect Carbapenemase Detection: A Validated Procedure to Clearly Distinguish between Carbapenemase-Positive and Carbapenemase-Negative Bacterial Strains. Anal. Bioanal. Chem. 2013, 405, 5259-5266. [CrossRef] [PubMed]

42. Hrabák, J.; Chudác ková, E.; Walková, R. Matrix-Assisted Laser Desorption Ionization-Time of Flight (MALDITOF) Mass Spectrometry for Detection of Antibiotic Resistance Mechanisms: From Research to Routine Diagnosis. Clin. Microbiol. Rev. 2013, 26, 103-114. [CrossRef] [PubMed]

43. Sparbier, K.; Schubert, S.; Weller, U.; Boogen, C.; Kostrzewa, M. Matrix-Assisted Laser Desorption Ionization-Time of Flight Mass Spectrometry-Based Functional Assay for Rapid Detection of Resistance against $\beta$-Lactam Antibiotics. J. Clin. Microbiol. 2012, 50, 927-937. [CrossRef] [PubMed]

44. Mirande, C.; Canard, I.; Buffet Croix Blanche, S.; Charrier, J.P.; van Belkum, A.; Welker, M.; Chatellier, S. Rapid Detection of Carbapenemase Activity: Benefits and Weaknesses of MALDI-TOF MS. Eur. J. Clin. Microbiol. Infect. Dis. 2015, 34, $2225-2234$. [CrossRef] 
45. Rotova, V.; Papagiannitsis, C.C.; Skalova, A.; Chudejova, K.; Hrabak, J. Comparison of Imipenem and Meropenem Antibiotics for the MALDI-TOF MS Detection of Carbapenemase Activity. J. Microbiol. Methods 2017, 137, 30-33. [CrossRef] [PubMed]

46. Calderaro, A.; Buttrini, M.; Piergianni, M.; Montecchini, S.; Martinelli, M.; Covan, S.; Piccolo, G.; Medici, M.C.; Arcangeletti, M.C.; Chezzi, C.; et al. Evaluation of a Modified Meropenem Hydrolysis Assay on a Large Cohort of KPC and VIM CarbapenemaseProducing Enterobacteriaceae. PLoS ONE 2017, 12, e0174908. [CrossRef] [PubMed]

47. Miltgen, G.; Plésiat, P.; Mille, A.; Chatelain, P.; Fournier, D. Detection of Carbapenemase Activity in Pseudomonas Aeruginosa by Matrix-Assisted Laser Desorption Ionization-Time of Flight Mass Spectrometry (MALDI-TOF MS). J. Microbiol. Methods 2018, 145, 66-68. [CrossRef] [PubMed]

48. Hrabák, J.; Niemczyková, J.; Chudáčková, E.; Fridrichová, M.; Študentová, V.; Červená, D.; Urbášková, P.; Žemličková, H. KPC-2-Producing Klebsiella Pneumoniae Isolated from a Czech Patient Previously Hospitalized in Greece and in Vivo Selection of Colistin Resistance. Folia Microbiol. 2011, 56, 361-365. [CrossRef] [PubMed]

49. Lasserre, C.; de Martin, L.; Cuzon, G.; Bogaerts, P.; Lamar, E.; Glupczynski, Y.; Naas, T.; Tandé, D. Efficient Detection of Carbapenemase Activity in Enterobacteriaceae by Matrix-Assisted Laser Desorption Ionization-Time of Flight Mass Spectrometry in Less than 30 Minutes. J. Clin. Microbiol. 2015, 53, 2163-2171. [CrossRef]

50. Kulkarni, M.; Zurita, A.N.; Pyka, J.S.; Murray, T.S.; Hodsdon, M.E.; Peaper, D.R. Use of Imipenem to Detect KPC, NDM, OXA, IMP, and VIM Carbapenemase Activity from Gram-Negative Rods in 75 Minutes Using Liquid Chromatography-Tandem Mass Spectrometry. J. Clin. Microbiol. 2014, 52, 2500-2505. [CrossRef]

51. Monteferrante, C.G.; Sultan, S.; ten Kate, M.T.; Dekker, L.J.M.; Sparbier, K.; Peer, M.; Kostzrewa, M.; Luider, T.M.; Goessens, W.H.F.; Burgers, P.C. Evaluation of Different Pretreatment Protocols to Detect Accurately Clinical Carbapenemase-Producing Enterobacteriaceae by MALDI-TOF. J. Antimicrob. Chemother. 2016, 71, 2856-2867. [CrossRef]

52. Rodrigues, C.; Sousa, C.; Ramos, H.; Coque, T.M.; Cantón, R.; Lopes, J.A.; Peixe, L. Elucidating Constraints for Differentiation of Major Human Klebsiella Pneumoniae Clones Using MALDI-TOF MS. Eur. J. Clin. Microbiol. Infect. Dis. 2017, 36, $2856-2867$. [CrossRef] [PubMed]

53. Giordano, C.; Barnini, S. Rapid Detection of Colistin-Resistant Klebsiella Pneumoniae Using MALDI-TOF MS Peak-Based Assay. J. Microbiol. Methods 2018, 155, 27-33. [CrossRef]

54. Idelevich, E.A.; Sparbier, K.; Kostrzewa, M.; Becker, K. Rapid Detection of Antibiotic Resistance by MALDI-TOF Mass Spectrometry Using a Novel Direct-on-Target Microdroplet Growth Assay. Clin. Microbiol. Infect. 2018, 24, 738-743. [CrossRef] [PubMed]

55. Rodrigues, C.; Passet, V.; Rakotondrasoa, A.; Brisse, S. Identification of Klebsiella Pneumoniae, Klebsiella Quasipneumoniae, Klebsiella Variicola and Related Phylogroups by MALDI-TOF Mass Spectrometry. Front. Microbiol. 2018, 9. [CrossRef]

56. Lau, A.F.; Wang, H.; Weingarten, R.A.; Drake, S.K.; Suffredini, A.F.; Garfield, M.K.; Chen, Y.; Gucek, M.; Youn, J.H.; Stock, F.; et al. A Rapid Matrix-Assisted Laser Desorption Ionization-Time of Flight Mass Spectrometry-Based Method for Single-Plasmid Tracking in an Outbreak of Carbapenem-Resistant Enterobacteriaceae. J. Clin. Microbiol. 2014, 52, 2804-2812. [CrossRef] [PubMed]

57. Gato, E.; Constanso, I.P.; Rodiño-Janeiro, B.K.; Guijarro-Sánchez, P.; Alioto, T.; Arroyo, M.J.; Méndez, G.; Mancera, L.; Gut, M.; Gut, I.; et al. Occurrence of the P019 Gene in the BlaKPC-Harboring Plasmids: Adverse Clinical Impact for Direct Tracking of KPC-Producing Klebsiella Pneumoniae by Matrix-Assisted Laser Desorption Ionization-Time of Flight Mass Spectrometry. J. Clin. Microbiol. 2021, 59, 21. [CrossRef]

58. Cordovana, M.; Kostrzewa, M.; Glandorf, J.; Bienia, M.; Ambretti, S.; Pranada, A.B. A Full MALDI-Based Approach to Detect Plasmid-Encoded KPC-Producing Klebsiella Pneumoniae. Front. Microbiol. 2018, 9, 2854. [CrossRef] [PubMed]

59. Centonze, A.R.; Bragantini, M.; Lucchini, E.; Mazzariol, A. Laboratory Validation of a KPC-Producing Strain Identification Method Based on the Detection of a Specific 11,109 Da Peak via Maldi-Tof-Vitek MS in an Endemic Area. New Microbiol. 2019, 42, 114-117. [PubMed]

60. Neonakis, I.K.; Spandidos, D.A. Detection of Carbapenemase Producers by Matrix-Assisted Laser Desorption-Ionization Time-ofFlight Mass Spectrometry (MALDI-TOF MS). Eur. J. Clin. Microbiol. Infect. Dis. 2019, 38, 1795-1801. [CrossRef] [PubMed]

61. Migliorini, L.B.; de Sales, R.O.; Koga, P.C.M.; Doi, A.M.; Poehlein, A.; Toniolo, A.R.; Menezes, F.G.; Martino, M.D.V.; Gales, A.C.; Brüggemann, H.; et al. Prevalence of Blakpc-2, Blakpc-3 and Blakpc-30_Carrying Plasmids in Klebsiella Pneumoniae Isolated in a Brazilian Hospital. Pathogens 2021, 10, 332. [CrossRef] [PubMed]

62. Partridge, S.R. Tn4401 Carrying BlaKPC Is Inserted within Another Insertion in PKpQIL and Related Plasmids. J. Clin. Microbiol. 2014, 52, 4448-4449. [CrossRef]

63. Yao, H.; Cheng, J.; Li, A.; Yu, R.; Zhao, W.; Qin, S.; Du, X.D. Molecular Characterization of an IncFIlk Plasmid Co-Harboring BlaIMP-26 and Tet(A) Variant in a Clinical Klebsiella Pneumoniae Isolate. Front. Microbiol. 2020, 11, 1610. [CrossRef]

64. Rada, A.M.; de la Cadena, E.; Agudelo, C.; Capataz, C.; Orozco, N.; Pallares, C.; Dinh, A.Q.; Panesso, D.; Ríos, R.; Diaz, L.; et al. Dynamics of BlaKPC-2 Dissemination from Non-CG258 Klebsiella Pneumoniae to Other Enterobacterales via IncN Plasmids in an Area of High Endemicity. Antimicrob. Agents Chemother. 2020, 64, 174320. [CrossRef] [PubMed]

65. Gootz, T.D.; Lescoe, M.K.; Dib-Hajj, F.; Dougherty, B.A.; He, W.; Della-Latta, P.; Huard, R.C. Genetic Organization of Transposase Regions Surrounding BlaKPC Carbapenemase Genes on Plasmids from Klebsiella Strains Isolated in a New York City Hospital. Antimicrob. Agents Chemother. 2009, 53, 1998-2004. [CrossRef] [PubMed] 
66. Espinal, P.; Nucleo, E.; Caltagirone, M.; Mattioni Marchetti, V.; Fernandes, M.R.; Biscaro, V.; Rigoli, R.; Carattoli, A.; Migliavacca, R.; Villa, L. Genomics of Klebsiella Pneumoniae ST16 Producing NDM-1, CTX-M-15, and OXA-232. Clin. Microbiol. Infect. 2019, 25, 385.e1-385.e5. [CrossRef] [PubMed]

67. Chen, L.; Chavda, K.D.; al Laham, N.; Melano, R.G.; Jacobs, M.R.; Bonomo, R.A.; Kreiswirth, B.N. Complete Nucleotide Sequence of a BlaKPC-Harboring IncI2 Plasmid and Its Dissemination in New Jersey and New York Hospitals. Antimicrob. Agents Chemother. 2013, 57, 5019-5025. [CrossRef]

68. Chen, J.; Lu, J.; Zhang, R.; Cai, J. Antibiotic Resistance and Virulence Characteristics Analysis of a Carbapenem-Resistant Hypervirulent Klebsiella Pneumoniae. Natl. Med J. China 2021, 101, 3143. [CrossRef]

69. Ho, P.L.; Cheung, Y.Y.; Lo, W.U.; Li, Z.; Chow, K.H.; Lin, C.H.; Chan, J.F.W.; Cheng, V.C.C. Molecular Characterization of an Atypical IncX3 Plasmid PKPC-NY79 Carrying Bla KPC-2 in a Klebsiella Pneumoniae. Curr. Microbiol. 2013, 67, 493-498. [CrossRef] [PubMed]

70. Chen, Q.; Zhou, J.; Wu, S.; Yang, Y.; Yu, D.; Wang, X.; Wu, M. Characterization of the IncX3 Plasmid Producing BlaNDM-7 From Klebsiella Pneumoniae ST34. Front. Microbiol. 2020, 11, 1885. [CrossRef] [PubMed]

71. Figueroa-Espinosa, R.; Costa, A.; Cejas, D.; Barrios, R.; Vay, C.; Radice, M.; Gutkind, G.; di Conza, J. MALDI-TOF MS Based Procedure to Detect KPC-2 Directly from Positive Blood Culture Bottles and Colonies. J. Microbiol. Methods 2019, 159, 120-127. [CrossRef] [PubMed]

72. Yoon, E.J.; Lee, E.H.; Hwang, D.H.; Lee, H.; Baek, J.H.; Jeong, S.H. Direct Detection of Intact Klebsiella Pneumoniae Carbapenemases Produced by Enterobacterales Using MALDI-TOF MS. J. Antimicrob. Chemother. 2020, 75, 1174-1181. [CrossRef] [PubMed]

73. Hleba, L.; Hlebová, M.; Kováčik, A.; Šmehýl, P.; Hricáková, N.; Petrová, J.; Shariati, M.A.; Čuboň, J. Escherichia Coli as a Carrier of Tetracyclines and Penicillins Resistance in Wild Pheasant (Phasianus Colchicus). J. Environ. Sci. Health-Part A Toxic/Hazard. Subst. Environ. Eng. 2020, 55, 1201-1209. [CrossRef]

74. EUCAST. EUCAST Disk Diffusion Method for Antimicrobial Susceptibility Testing; ESCMID: Basel, Switzerland, 2017 ; Volume 6.

75. EUCAST. Breakpoint Tables for Interpretation of MICs and Zone Diameters. Version 11.0. 2021. Available online: http: //www.eucast.org (accessed on 1 January 2021).

76. Pillai, D.R.; Melano, R.; Rawte, P.; Lo, S.; Tijet, N.; Fuksa, M.; Roda, N.; Farrell, D.J.; Krajden, S. Klebsiella Pneumoniae Carbapenemase, Canada. Emerg. Infect. Dis. 2009, 15, 827-829. [CrossRef] [PubMed]

77. Niedermeyer, T.H.J.; Strohalm, M. MMass as a Software Tool for the Annotation of Cyclic Peptide Tandem Mass Spectra. PLoS ONE 2012, 7, e44913. [CrossRef] [PubMed] 